\title{
TTR
}

Traduction, terminologie, rédaction

\section{Breaking the Linguistic Minority Complex through Creative Writing and Self-Translation}

\section{Arianna Dagnino}

Volume 32, numéro 2, 2e semestre 2019

La politique des microcentres : la traduction dans des contextes " mineurs » comme transfert culturel complexe

The Politics of Micro-Centers: Translation in "Minor" Contexts as Complex Cultural Transfer

URI : https://id.erudit.org/iderudit/1068905ar

DOI : https://doi.org/10.7202/1068905ar

Aller au sommaire du numéro

Éditeur(s)

Association canadienne de traductologie

ISSN

0835-8443 (imprimé)

1708-2188 (numérique)

Découvrir la revue

Citer cet article

Dagnino, A. (2019). Breaking the Linguistic Minority Complex through Creative Writing and Self-Translation. TTR, 32(2), 107-129.

https://doi.org/10.7202/1068905ar

\section{Résumé de l'article}

Une langue minoritaire peut se définir de façon générale comme une langue parlée par moins de $50 \%$ de la population d'une région, d'un État ou d'un pays donné (Grenoble et Singerman, 2017, n.p.). Dans le présent article, je propose une définition plus contextualisée qui s'applique au domaine de la création littéraire et de l'autotraduction. Je considère ainsi une langue comme étant minoritaire lorsqu'un écrivain bilingue ou plurilingue la perçoit comme n'étant pas la langue dominante dans le contexte socioculturel et linguistique dans lequel il est actif en tant qu'auteur et (auto)traducteur. En prenant comme point de départ cette définition alternative, je traite de la pratique créative et autotraductive de l'écrivain canadien Antonio D'Alfonso. D'Alfonso est l'un des rares écrivains plurilingues qui se sentent défamiliarisés linguistiquement. Il affirme qu'au lieu d'avoir une langue maternelle il dispose d'un bagage mixte de dialecte molisano, de français, d'anglais et d'italien. Ainsi, il a tendance à écrire, à penser et à (auto-)traduire en étant immergé dans une sorte de paysage linguistique en 3D (voire en 4D) (Pivato, 2002). Vues sous cet angle, ses autotraductions du français vers l'anglais ou inversement témoignent de la façon expérimentale avec laquelle il remet en question la "soumission brute " (Whyte, 2002, p. 69) d'une langue sur une autre et surmonte tout complexe linguistique minoritaire qu'il aurait pu développer dans son parcours pour devenir un écrivain linguistiquement déraciné.
Ce document est protégé par la loi sur le droit d'auteur. L’utilisation des services d’Érudit (y compris la reproduction) est assujettie à sa politique d'utilisation que vous pouvez consulter en ligne.

https://apropos.erudit.org/fr/usagers/politique-dutilisation/ 


\title{
Breaking the Linguistic Minority Complex through Creative Writing and Self-Translation
}

\author{
Arianna Dagnino \\ University of British Columbia
}

\begin{abstract}
Generally speaking, a minority language is "one spoken by less than 50 percent of a population in a given region, state or country" (Grenoble and Singerman, 2017 , n.p.). In this article, I propose a more contextualized definition that applies to the realm of literary writing and (self-)translation. Thus, I define a minority language as any language which a bilingual or plurilingual writer perceives as not being the dominant one in the sociocultural and linguistic context in which s/he is active as an author or as a (self-)translator. Assuming this alternative definition as a point of departure, I discuss the creative and selftranslational practice of the Canadian writer Antonio D'Alfonso. D'Alfonso is one of those rare plurilingual writers who feel linguistically defamiliarized, claiming that instead of having a proper mother tongue he has a mixed baggage of native Molisano dialect, French, English and Italian. Thus, he tends to write, think and (self-)translate immersed in a kind of 3D- (or even 4D-) linguistic landscape (Pivato, 2002). D'Alfonso's self-translations from French into English and/or vice versa are testimony to the author's experimental way of challenging the "crude subjugation" (Whyte, 2002, p. 69) of a language over another and of overcoming any minority-language complex he might have developed on his path to becoming a linguistically uprooted writer.
\end{abstract}

Keywords: self-translation, minor language, dominant language, transcultural, bilingual writers

\section{Résumé}

Une langue minoritaire peut se définir de façon générale comme une langue parlée par moins de $50 \%$ de la population d'une région, d'un État ou d'un pays donné (Grenoble et Singerman, 2017, n.p.). Dans le présent article, je propose une définition plus contextualisée qui s'applique au domaine de la création littéraire et de l'autotraduction. Je considère ainsi une langue comme étant minoritaire lorsqu'un écrivain bilingue ou plurilingue la perçoit comme nétant pas la langue dominante dans le contexte socioculturel et linguistique dans lequel il est actif en tant qu'auteur et (auto)traducteur. En prenant comme 
point de départ cette définition alternative, je traite de la pratique créative et autotraductive de l'écrivain canadien Antonio D'Alfonso. D'Alfonso est l'un des rares écrivains plurilingues qui se sentent défamiliarisés linguistiquement. Il affirme qu'au lieu d'avoir une langue maternelle il dispose d'un bagage mixte de dialecte molisano, de français, d'anglais et d'italien. Ainsi, il a tendance à écrire, à penser et à (auto-)traduire en étant immergé dans une sorte de paysage linguistique en 3D (voire en 4D) (Pivato, 2002). Vues sous cet angle, ses autotraductions du français vers l'anglais ou inversement témoignent de la façon expérimentale avec laquelle il remet en question la «soumission brute" (Whyte, 2002, p. 69) d'une langue sur une autre et surmonte tout complexe linguistique minoritaire qu'il aurait pu développer dans son parcours pour devenir un écrivain linguistiquement déraciné.

Mots-clés : auto-traduction, langue mineure, langue dominante, transculturel, écrivains bilingues

\section{Introduction}

In this article, I discuss the way in which, more or less consciously, the polyglot and translingual Canadian writer Antonio D'Alfonso uses creative writing and self-translation to overcome his minoritylanguage complex and to symbolically minorize-that is, decentralize - the main dominant languages (English and French) in which he happens to be creatively active. Methodologically, I mainly draw upon an interview with D'Alfonso. Conceptually, I assume a transcultural perspective which, at the macro-level, looks beyond the divides between languages and cultures in search of their commonalities, entanglements, and amalgamations (Welsch, 2010), and at the microlevel pays attention to the individual's multiple, cross-cutting cultural interconnections and identity formations (Epstein, 2009).

\section{Major and Minor Languages in the Global Ecumene of Letters}

In its common understanding, a minority language is "one spoken by less than 50 percent of a population in a given region, state or country" (Grenoble and Singerman, 2017, n.p.). However, if we look at the complex web of power dynamics at play in the "global galaxy" of languages (De Swaan, 1993, 2001) and in the "World Republic of Letters" (Casanova, 2004), we are confronted with a range of asymmetric relations that further complicates the perception of what is minor and major, central and peripheral, dominant and subordinate, canonized and non-canonized. Drawing upon Abram De Swaan's (1993) model of the "galaxy of languages," Pascale Casanova (2004, 2009) attaches different levels of symbolic capital to each and every literary national system. National literatures compete for dominance 
in the global ecumene of letters, instituting a system of centre and periphery. Thus, according to Casanova, the major literary power brokers are still to be found in the West-London, Paris (more particularly), and New York. Consequently, the same inequalities, hierarchies, and power struggles that are at play within and between nations - where we currently witness a manifest predominance of the Anglo-American cultural sphere-also determine the fate and the global standing of national/ethnic languages and their related literatures within and outside national borders (Grutman, 2015). As Rainier Grutman reminds us,

Significa que hay desgraciadamente diferencias apreciables entre las lenguas del mundo en términos de Mercado y de valor de intercambio (!que es otra cosa muy distinta del valor intrínseco!) (2011, p. 79)

[It means that unfortunately there are considerable differences between the world's languages in terms of market and exchange value (which is something quite different from intrinsic value!] (my translation)

However, it is worth taking into consideration that in an increasingly pluricentric linguistic world even the prestige, qualitative prominence, and weight of national languages tend to vary dramatically depending on the context and the literary stature of writers and (self-) translators. According to Eva Hoffman,

there is no one geographic center pulling the world together and glowing with the allure of the real thing [...] in a decentered world we are always simultaneously in the center and on the periphery [...] every competing center makes us marginal. (1989, pp. 274-275) ${ }^{1}$

Having said that, at this moment in time we may undoubtedly consider English as the global dominant language, that is, the idiom with the highest symbolic and real capital in the so-called global "stock exchange of languages" (Calvet, 2006, p. 4; see also Grutman, 2011, 2015). At an international level, English is the established language of communication in any major field of human activity: diplomacy, business, finance, science, technology, publishing, travel, tourism, research, and academia (Phillipson, 2009; Galloway and Rose, 2015). Any other language-including major ones such as French, Spanish, Arabic, and Chinese — needs to be evaluated against

1. Casanova (2004) also acknowledges that in most recent times literary production and marketplace are increasingly becoming pluricentral, thus overcoming the traditional dichotomy between centre and periphery, as well as between developed and underdeveloped literary systems. 
the benchmark set by English, and thus provided with its specific "power differential." We might thus establish a basic rule: the less linguistic capital a language has in the world stock exchange of idioms, the higher its power differential is. Hence, if Spanish has a low power differential towards English and French even a lower one, Tagalog has a high-power differential, and Gikuyu has an even higher one. In very specific and extremely localized contexts, the power differential between English and another major language can be more or less artificially kept to a minimum, or heavily constrained. It is the case, for example, with English in the Quebec context, where language laws are notably meant to mitigate the linguistic power divide and "increase the status of French relative to English in the Province" (Bourhis, 2001, p. 101).

In this article, however, I would like to propose a more contextualized definition of minority language applied to the realm of literary writing and (self-)translation. A minority language is any language which a bilingual or plurilingual writer perceives as not being the dominant one in the socio-cultural and linguistic context in which s/he is creatively active (either by choice, life's circumstances or outer forces) as an author and/or as a (self-)translator.

Let's take the example of Tim Parks, a British writer who has been living in Italy for most of his adult life. For many years, Parks wrote and published in English, his mother tongue (and, as we said, the accepted global dominant language). At a certain stage of his literary career, he felt compelled to write and self-translate his work into Italian, since Italian is the idiom in which he is culturally immersed for most of the time. Yet, Parks confesses to have miserably failed at both-writing in or self-translating into Italian. He found the tasks too impervious, almost impossible, and the results not good enough for his taste, lacking the necessary depth:

[It is] my own growing conviction that a very great deal of literature, poetry, and prose can only be truly exciting and efficacious in its original language, a conviction that goes hand in hand with my decision not to write any more in Italian, never to translate into Italian, and never to translate except for the purposes of elucidation. This is a personal decision, I should stress, not a prescription. (Parks, 2000, n.p.)

2. The way I use the expression power differential is similar to the way Castro, Meiner and Page talk about the power differential between two languages (2017, p. 2). 
Despite his admitted failures, Park's attempts at bilingual writing and at self-translation show that even authors writing in a major, dominant language may perceive it as minor if that language is not shared, acknowledged, or regularly practiced by the literary community of their adopted country.

\section{A Taxonomy of Self-translation in Relation to Symbolic Capital}

Anton Popovič initially defined self-translation as "the translation of an original work into another language by the author himself" (1976, p. 19). In this article, I adopt Grutman's extended definition of selftranslation as both a process and a product: "the act of translating one's own writings into another language and the result of such an undertaking" (2009, p. 257).

In the world's linguistic stock exchange described by De Swaan and Casanova, and further explored by Grutman (2015), translations (and thus also self-translations) can be either horizontal or vertical, depending on the value given to the languages involved. They are horizontal when they happen between national languages that have the same linguistic capital, that is, when the languages involved are equally juxtaposed, autonomous, dominant, and belong to wellestablished national literary systems. They are vertical when they "mettent en présence des langues de statut trop inégal pour que le transfert puisse ressembler à un échange (mot qui implique une forme de réciprocité" [they involve languages whose status is too unequal to resemble a veritable "exchange" (a word that implies a form of reciprocity] (Grutman 2015, p. 21; my trans.).

Vertical translations may further be qualified as "supraductions" if the text is translated with an ascending movement (uphill), from a minor language into a dominant and more central one, or, in other words, from the periphery to the centre; or they can be "infraductions" if the text is translated with a descending movement (downhill), from a major and more widespread language into a minor and marginalized one, that is, from the centre to the periphery (ibid.). The same distinction applies to self-translation, which can be thought of as "infraautotraducción" (infraself-translation) or "supraautotraducción" (supraself-translation; Grutman, 2011, p. 81). ${ }^{3}$

3. With regard to self-translation according to the unequal power relations between languages, and thus its differentiation into vertical or horizontal, endogenous or exogenous, symmetrical or asymmetrical, see also Grutman (2013) and Ferraro and Grutman (2016). 


\section{Bilingualism and Self-translation}

The reasons why nowadays writers decide to self-translate their work are manifold (economic, psychological, sociological, aesthetic, or cultural) $)^{4}$ and often linked to growing migratory flows, which create new generations of bilingual or semi-bilingual writers. In this article, the category "semi-bilingual" mainly refers to writers who were not raised as bilingual since their birth but who, due to a series of circumstances, happened (more or less forcefully, more or less willingly) to become bilingual in their youth or later in life. In her book Nord Perdu, the bilingual (French/English) writer Nancy Huston makes a similar distinction between "les vrais bilingues" and "les faux bilingues" (1999, p. 53).

In an attempt at summarizing-accepting the risk of simplifying-for the purposes of study, we may thus say that writers decide to self-translate in order to: ${ }^{5}$

- Sell their book: that is, to find interested publishers in their country of adoption. ${ }^{6}$ This happens especially with aspiring authors who are in the process of becoming bilingual, and often avail themselves of the help of native speakers. I call these writers the Sellers and the product of their self-translation the sellable.

- Widen their readership or expose their work to a wider international market: that is, acquire recognition-and, possibly, financial gain-in the dominant language. ${ }^{8}$ This happens especially with emerging writers or mid-career writers who are also in the process of becoming fully bilingual and who are keen to give their work "an afterlife" in their adopted language (Grutman, 2013, p. 71). I call them the Wideners (or the Exposers) and the product of their self-translation the widened (or the exposed).

- Maintain a degree of ownership, autonomy, and/or authoriality. This especially happens with mid-career writers or with writers who belong to linguistic/ethnic minorities. These writers

4. See Anselmi (2012), Beaujour (1989), Gentes (2016), and Hokenson and Munson (2007).

5. On the reasons that lead writers to self-translate, see in particular Bassnett (2013), Ferraro and Grutman (2016), Grutman (2015), and Nannavechia (2016).

6. See Krause (2007) and Gentes (2016).

7. An example can be the self-translation from Hebrew into English of Lee Kofman's novel The Dangerous Bride (2014).

8. See Bueno García (2003). 
can be either semi- or fully bilingual. ${ }^{9}$ While some authors are particularly interested in the politics of promoting a minority language against the dominance of a major language, others confess to self-translate in order to "rescue" their work from mistranslation or to "avoid inaccuracy" (Krause, 2007). ${ }^{10} \mathrm{I}$ call them the Owners (or the Authorialists) and the product of their selftranslation the owned (or the authorialised). Indeed, irrespective of their actual qualities, self-translations are often considered superior to non-authorial translations. This is due to the fact that, as Brian T. Fitch remarks, "the writer-translator is no doubt felt to have been in a better position to recapture the intentions of the author of the original than any ordinary translator" (1988, p.125). Moreover, self-translators have the authority to allow themselves shifts in the translation that might not be "allowed" by another translator.

- Reflect their bilingual identity and bicultural intermediation. This happens especially with mid-career or established writers who are at least semi-bilingual and in the process of becoming fully bilingual. ${ }^{11}$ As an unidentified writer in Corinna Krause's study states: "I like seeing the same idea expressed in the other language; getting a bilingual perspective on what I'm actually trying to say $[\ldots]$. I [...] like the challenge of making it work in the second language" (2007, p. 110). I call them the Bireflectors (or the Intermediaries) and the product of their self-translation the bireflected (or the intermediated). ${ }^{12}$

- Explore or exploit self-translation as a creative device that enables them to rewrite, reshape, alter, or reword their originals. This especially happens with well-established writers and fully bilingual writers. I call them the Explorers (or the Exploiters) and the product of their self-translation the explored (or the exploited). It is particularly in this case that writers have the unique opportunity of accessing a sphere of "added creativity"

9. See Krause (2007) and Gentes (2016).

10. An example can be Amara Lakhous's self-translation of his work Scontro di civiltà per un ascensore a piazza Vittorio from Arabic into Italian. See in this regard Grutman (2016).

11. See Hokenson (2013).

12. An example is the translation from Spanish to English of Carmen Rodriguéz's novel Retribution (2011). 
by exploiting and exploring their privileged double status of authors and authorized agents (Besemeres and Wierzbicka, 2007; Grutman and Van Bolderen, 2014). Suffice it to think of the self-translation practice of Samuel Beckett, Nancy Huston, or André Brink. Brink once remarked: "it depends very much on the mind-set and on the way that you want to approach it [self-translation], whether it is going to be disrupting or creative, whether it is going to add something to you or take something away from you" (cited in Recuendo Peñalver, 2015).

- Majorize or decentralize a language. A writer may decide either to give relevance to a minor language by self-translating his/ her work into that language from a major one (majorization), or to decentralize and diminish the self-importance of two equally dominant languages by self-translating one into the other (decentralization). Depending on the case, I respectively call this kind of self-translators the Majorizers (and the product of their self-translation the majorized), and the Decentralizers (and the product of their self-translation the decentralized). This approach is not dissimilar to the one described by Grutman in regard to a certain way of using "supraself-translation" —and, even more so, "infraself-translation," according to which:

el escritor mantiene visibles ambas lenguas en una producción total, que es, por lo tanto, bilingüe. No sacrifica el escritor su habla nativa en el altar de la "gran" lengua supuestamente "universal," sino que mantiene el contacto con el público de su comunidad de origen, cuyo idioma quizás se considere menos prestigioso pero que le da un sello de autenticidad. (2011, p. 84)

[The writer keeps both languages visible in a total production, which is therefore bilingual. The writer does not sacrifice his native speech to the altar of the supposedly "great," "universal" language, but maintains contact with the public of his community of origin, whose language may be considered less prestigious but which gives it a stamp of authenticity.] (my trans.)

Gilles Deleuze and Félix Guattari (1975) have explored and revealed the power of "minor literatures" for destabilizing dominant social codes. In the same way, and to a certain extent, minor languages in self-translation may act as tools to subvert, escape from and, possibly, decentralize the dominant role of any language perceived as "major" in a particular cultural context. As Christian Lagarde explains: 
La subjectivité, liée à une survalorisation symbolique, tend alors à inverser dans le texte [...] le rapport de force réel, de la même manière que, selon Deleuze et Guattari (1975), une "langue mineure" forgée par l'écrivain parvient à déstabiliser de l'intérieur (à faire boiter) quelque langue que ce soit. (2015, p. 6)

This artificial and rather generic categorization of self-translators according to their aspirations, aims, and self-perceived level of bilingualism provides us with a useful interpretive frame regarding the reasons that may lead writers to self-translate and to the kind of self-translation they produce. However, we must keep in mind that these categories are neither fixed nor impervious: they tend instead to overlap, intersect or conflate into each other. Moreover, once they embark on the process of self-translation, writers tend to jump from one box to the other over the course of time-and, sometimes, even within the same book-depending on their publishing status, cultural manifestations, identity issues, or exploratory/creative drives.

\section{Majorizing a Minor Language through Writing and Self- translation}

As we have seen, despite the unequal power relations between languages in the global scene (Casanova, 2009; Grutman, 2015), a perceived minority language can - through a subversive creative or translational act-be majorized, thus disrupting the binary ideological framework of what is minor and what is major, what is dominant and what is subaltern, what is relevant and what is irrelevant. There are several reasons that lead an author to majorize a language and several ways to do it, whether consciously or subconsciously, defiantly or placidly.

Let's take the case of Jhumpa Lahiri. After having acquired fame and literary success by writing in English and publishing with major American publishing houses, Lahiri decided to abandon English and write in her newly adopted language, Italian. Echoing Beckett's famous explanation for his turn to French ("parce qu'en français c'est plus facile d'écrire sans style"-because in French it's easier to write without style), Lahiri declared: "In italiano scrivo senza stile, in modo primitivo" (In Italian I write without style, in a primitive way") (2015, pp. 52-53). Lahiri chose Italian to find a freer way of writing, without having to keep up with the expectations created by her nuanced English style (see Kellman, 2017). She published her first book in Italian - a memoir - with an Italian publisher. She was so adamant 
about wanting to revel in the new expressive freedom provided by Italian (a third language painstakingly acquired in her adult age) that she even refused to self-translate her work into English, leaving the translation task to a professional translator, Ann Goldstein. The translation appeared in a bilingual edition, with Lahiri's Italian on one side and Goldstein's English on the other, thus placing the two languages on an equal footing even from a visual point of view. By choosing to write and publish in Italian, Lahiri found a creative way to dislocate the centrality of English. Not surprisingly, the book was an instant success. One wonders, however, whether it would have met the same enthusiastic reception if, instead of Italian, Lahiri had chosen a language less appealing and with a lesser symbolic capital, such as Finnish or Yoruba.

The case of Ngugi Wa Thiong'o is even more radical in this regard, and, more particularly, in the context of self-translation. After writing several successful novels in English, Wa Thiong'o decided to go back to his native Gikuyu (Baker, 2017). Now, every time he writes a play or a novel in his Kenyan mother tongue, he self-translates it into English, making sure that on the cover of the book there is written: "Translated from Gikuyu by the Author." In this act of creative and translational resistance, Wa Thiong'o not only honors and ennobles the linguistic tradition in which he is active but also tries to reduce the power differential between Gikuyu and the (post)colonial language, English. Indeed, as Homi Bhabha reminds us, "[c]ultural translation desacralizes the transparent assumptions of cultural supremacy" (1994, p. 228).

Although in a more veiled and subtle way, Francesca Duranti also decentralizes the English of her self-translated novel Left-Handed Dreams by infusing it with a certain ethnic flavor- "a scent of basil," as she calls it (Dagnino and Duranti, 2017). She does so by making sure that certain turns of the phrase, linguistic quirks, and neologisms in her prose in English act as a reminiscence of her native Italian. For example, she insisted in keeping the neologism "to de-southernize" (demeridionalizzare) in relation to accents and dialects, and in keeping the Italian word "naturalezza" (naturalness) — another way of referring to the concept of "sprezzatura" (ibid.).

The examples here provided deal with language combinations that, according to the global linguistic stock exchange, are considered asymmetrical - the English having certainly more symbolic capital 
than Italian or Gikuyu. At any rate, it is difficult to deny that major writers, that is writers endowed with enough symbolic capital at an international - or at least national-level, have more chances to successfully majorize a minor language. Success, in this case, might mean to be acknowledged for one's writing attempts by the Englishbased media establishment or by the international academic community. Thus, if Jhumpa Lahiri has been lauded for her creative endeavors in Italian by no less than The New Yorker ${ }^{13}$, Ngugi Wa Thiong'o has, for his part, become the champion of postcolonial literati. As Susan Bassnett notes, among many others,

[t]he case of a writer like Ngugi Wa Thiong'o reveals a shift of language as a means of asserting the status of a minority language. Ngugi chose to make a political statement by rejecting English, the global language, by preferring to write in Gikuyu. (2013, p. 18)

Undoubtedly, writers who are successful according to the parameters adopted, or imposed, either by the global market or by a consecrated literary community are more willingly allowed those poetic licenses that, in other cases, might be easily disapproved of, rejected, or simply not registered-obliterated behind a wall of silence. As we shall see in the case of Antonio D'Alfonso, minor writers, that is writers (self-)perceived as literary outsiders, have a much harder time when they, more or less consciously, more or less subtly, try to decentralize a major language through self-translation. Most of the time their attempts are perceived as linguistic faults, blunders, naïvetés, improprieties, betrayals, or awkward efforts to get free of a particular national literary mold.

\section{Antonio D'Alfonso: A Writer without a (Dominant) Tongue}

Together with Alberto Manguel, Antonio D'Alfonso is one of those rather rare cases of plurilingual writers who constantly feel linguistically destabilized or defamiliarized (Dagnino and D'Alfonso, 2017). ${ }^{14}$ Put it simply, D'Alfonso claims that, instead of having a pro-

13. See Leyshon (2018).

14. The Argentinian-Canadian and polyglot writer Alberto Manguel considers not Spanish but rather English-which his mother did not speak-his mother tongue. "I was looked after by a nanny who was a German-speaking Czech; she taught me English and German and those were my languages until the age of seven; in fact, I didn't speak with my parents till that age: they spoke Spanish and French, so I got to know them when we returned to Argentina and I learned Spanish" (Dagnino and Manguel, in Dagnino, 2015, p. 75). 
per mother tongue, he has a mixed baggage of native Molisano dialect (literally, his mother's tongue), French (the language of his youth in Quebec), English (the language of his schooling), and Italian (the language of his doctorate studies):

I do not feel at home in any language. All languages are foreign to me. A language is a tight suit I have to wear... I have no language, and so I feel awkward with them all, and I am extremely clumsy when dealing with language. (ibid.)

Not only is D'Alfonso a writer without a dominant tongue, he also considers himself a writer without a voice, due to the fact that he feels he never broke through the literary scene, whichever this may be: the English Canadian, the French Canadian or the Italian. In our interview, he stated:

I have been published in English, French, and Italian. I was able to get my work published because of a diversity of outlets. But none of these outlets can be considered powerful outlets. Because I have never been produced on the official stage of world literature [...], I do not exist at all. All my voices are silenced and will eventually dissipate into the emptiness of indifference. In truth, I would consider myself an aphonic writer. A writer without a voice. (ibid.)

D'Alfonso is still in search of an audience, and thus he keeps selftranslating. Here is his straight and honest answer to the question "Why do you self-translate?":

I translate myself because no one else wants to translate me [...]. Translation is about fulfilling the needs of an audience... There is nothing extraordinary about translation. It should be done systematically. (ibid.)

And if major publishers don't notice you-D'Alfonso implies-you can still try to have a voice in another language, in another literary realm, in another official culture-in an attempt to break the wall of silence of your "minority" status.

\section{D'Alfonso's Self-translation: A Case in Linguistic Dislocation}

Born in Montreal, the son of Italian parents, in his long quest for a linguistic and cultural home D'Alfonso has been creatively writing in English, French and Italian (Pivato, 2002). Due to his selfperceived and self-confessed "linguistic atheism"-as he calls it in our interview-he tends to write, think, and (self-)translate immersed, or lost, in a kind of 3D- (or even 4D-) linguistic landscape (Dagnino and D'Alfonso, 2017). There seems to be no dominant, ur-language 
he can go back to or rely upon (ibid:; see also Shafiq, 2006) but rather a constant shift from one linguistic realm to another and back. As Joseph Pivato observes, commenting on D'Alfonso's sense of linguistic and cultural homelessness emerging from his poetic self-translations, "poem after poem the sense of loss is traced in three dimensions with geometric precision" (2002, p. 247). In our in-depth interview (Dagnino and D'Alfonso, 2017), D'Alfonso repeatedly remarks how, at any given moment of his life, he felt out of tune with the majority language of the local community around him. It was the case with his mother's Molisano dialect when he was a toddler in Montreal, with the English of his schooling while he was living in Quebec, with his fluent French-Québécois when he moved to English-speaking Toronto, with his heavily dialectized Italian when he first visited Italy and tried to break through the Italian literary scene. It is exactly due to this feeling of linguistic displacement that D'Alfonso's self-translations end up acting as a reaction against the persisting domination of a language over another. ${ }^{15}$ In this regard, his multilingual poem "Babel"-a mix of Italian, French, English, and even Spanish-published in the collection The Other Shore works as a poetic manifesto, capturing and at the same time celebrating the condition of the multilingual individual in multicultural Canada (Pivato, 2002, p. 248). The poem reads as follows:

\author{
Nativo di Montreal \\ élevé comme Québecois \\ forced to learn the tongue of power \\ vivi en Mexico como alternativa \\ figlio del sole e della campagna \\ par les franc-parleurs aimé \\ finding thousands like me suffering \\ me case y divorcié en tierra fria \\ nipote di Guglionesi \\ parlant politique malgré moi \\ steeled in the school of Old Aquinas \\ queriendo luchar con mis amigos latinos \\ Dio where shall I will be demain \\ (trop vif) qué puedo saber yo \\ spero che la terra be mine (D’Alfonso, 1988, p. 57)
}

Seen in this light, D'Alfonso's published and unpublished selftranslations from French into English and/or vice versa are testimony

15. See Whyte (2002). 
to his experimental way of counteracting the "crude subjugation" (Whyte, 2002, p. 69) of a language over another and of opposing any kind of minority-language complex he might have developed on his path to becoming a linguistically uprooted writer. In his creative hands and in his readers' reception, self-translation thus seems to act as a dislocating device able to decentralize-in that constant switching from one language to another-even two dominant idioms like English and French. As Grutman reminds us,

L'inclusione di una lingua implica l'esclusione di un'altra, di modo che la scelta "positiva" [di una lingua] ha anche un lato "negativo", che ne inverte i valori tonali (come fa l'immagine negativa di una fotografia). (2016, p. 11)

[The inclusion of a language implies the exclusion of another, so that the "positive" choice [of a language] has also a "negative" side, which inverts its tonal values (like the negative image of a photography does]. (my trans.)

If, according to D'Alfonso, every language is a nationalistic tool and thus "irrefutably centralized," then translation may be used as a subversive "act of decentralization." This is how he puts it in our interview:

Self-translating in French or in English does not imply I possess a French or an English spirit. I come from elsewhere, and it is this "elsewhere" and how this affects the "here" and "now" that must be stressed. Not being from Britain or France liberates me from the canons of those specific traditions. I belong to no canon, and I make sure that this displacement is present in all my self-translations. (Dagnino and D'Alfonso, 2017)

D'Alfonso has been self-translating his works (poems, essays, novels, plays) from French to English (or vice versa) since the 1970s. Among others, he translated from French into English his novel Avril ou l'Anti-passion (1990) under the title Fabrizio's Passion (1995), his collection of poems $U_{n}$ ami, un nuage (2013) under the title $A n$ Irrelevant Man (2014), and his play Antigone (2004) under the same title, Antigone (2018). To his regret and admission, most of his works have gone generally unnoticed in the English Canadian literary scene. Even when his second novel $U n$ vendredi du mois d'aout-in this case translated into English by Jo-Anne Elder under the title $A$ Friday in August-won the Trillium Award in 2005, no one in Ontario seemed to notice. "This was a learning experience for me," D'Alfonso stated in our interview, adding: 
Not to expect anything anymore in literature [...]. If it were not for foreign scholars who have noticed some literary and cultural merit in what I have produced, I can say in all frankness that in English Canadaand, for that matter, French Canada-I do not exist as a poet, novelist, or essayist and this despite the thousands of pages that have appeared in almost 50 years of career. I mention this not to divulge any bitterness on my part. I am simply listing facts. (Dagnino and D'Alfonso, 2017)

Obviously, this condition of feeling almost "invisible" to the local or wider national literary scene-whether it is within a French or English Canadian context-is not peculiar to D'Alfonso alone. Many other bilingual/plurilingual writers belonging to minority ethnic communities in Canada share the same destiny (see, for example, Pivato, 2002). What is most striking in D'Alfonso's case, though, is his life-long attempt to build bridges and fill the on-going chasm between the two major and official languages of Canada from a thirdparty linguistic position (Italian/Molisano dialect) that would end up constantly challenging Canada's linguistic status quo.

It is not within the scope of this article to analyze and compare D'Alfonso's self-translations, which in most cases are produced through a creative process of rewriting, as the author is keen to underline:

The versions in the two languages are quite different from one another. [...] I do not believe that self-translation is translation at all, except as a librarian's category. Antigone in French is not the same as Antigone in English. There are subtleties that distinguish the two versions. The source is the same but the disclosures are different. (Dagnino and D’Alfonso, 2017)

In any case, other scholars have already aptly performed this task. Lucia Canton, among others, has revealed the highly creative nature of D'Alfonso's self-translations. About Avril ou l'anti-passion, which he translated as Fabrizio's Passion, she writes:

the author chose to publish an English adaptation of his original French novel instead of a straightforward translation. Essentially, the texts present the same narrative: Fabrizio Notte's quest for identity in a trilingual and tricultural environment. However, the specific language and cultural contexts that each inhabits makes the novel a different narrative experience in the writing, in the telling and in the reading. (Canton, 2015, n.p.)

What most of all I am interested in here is to understand the motivations, objectives, (self-)perception, and reception related to such 
translational practices. In this regard, we might even agree with D'Alfonso's provocation when he says he finds the whole exercise of comparing source text and target text useless, "self-referential" and a "tad arrogant" while we should rather focus on how the work is received/interpreted in a new linguistic context:

I never read Samuel Beckett by comparing his self-translations. The exercise seems to me scholarly and not at all literary. The fact that I write in two or three languages is not one's business except my own. It seems rather indecent to make a show of it, in fact. It is as though I were exposed for having multiple lovers. The serious issue about selftranslation is not about egotism, about the self. It is about breaking down borders, revealing to the world that there are no dissimilarities between language A and language B. Every language has to follow its codes, and what a writer does in one code might not work in another, so why bother to imitate the inimitable? Ticks are individual and, at times, though brilliant in one context, they might be insulting in another context. This over-emphasis on the lexis is a symptom of post-war literary practices that will in the future appear to be outdated mannerisms. I was never a believer of deconstructionism, and I believe that comparing original texts with their translations is very much the by-product of deconstructionism. (Dagnino and D'Alfonso, 2017)

In transcultural terms, D'Alfonso seems to be experiencing firsthand - and be revelling in - a cultural, literary, and linguistic state of "unbelonging" in his writing and (self-)translating (Dagnino, 2016, p. 7). In other words, he seems to have found his creative and linguistic raison d'être in an in-between and neutral cultural space of positive or wise estrangement in which even a felt sense of exclusion can be used in one's favor as a point of strength instead of as a weakness. In analyzing his unconventional modus operandi in his process of writing, translating and publishing his texts Avril ou l'anti-passion and Fabrizio's Passion, Canton mentions the author's way of writing passages or even whole chapters in three languages (Italian, English and French), thus showing how the process of translation had already started prior to the publication of the "original" French text. In doing so, she remarks: D'Alfonso "is illustrating more strongly what it means to be an artist who lives simultaneously in three languages, three cultures, three environments that cohabit one territory" (Canton, 2015, n.p.).

This state of unbelonging allows D'Alfonso a privileged, perhaps already transcultural, intellectual, and psychological dimension where 
he is able to feel quietly in place, rather than constantly out of place. As he states in our interview,

To be a bilingual-bicultural person is somewhat a lie. There is not a single day when a person is not bombarded by a variety of noise, music, voices, images. A writer should capture this influx of dimensions and include them in his work. I have never written simply in two languages. I have written always in as many languages as my mind can understand.

(Dagnino and D'Alfonso, 2017)

I open here a small parenthesis to elucidate my way of using the term unbelonging. Dubravka Ugresic has adopted this term in her book Europe in Sepia when talking about "the intoxication of belonging (to a home, a homeland, a country, a faith) and the trauma of unbelonging" (2014, p. 204). In a personal email exchange, the writer Inez Baranay has provided a different nuance to the concept of unbelonging, which adheres to a transcultural viewpoint: "the transcultural is a theoretical arena, in which the company is fine with a sense of belonging among the unbelonging." This outlook is not dissimilar to D'Alfonso's:

My culture is global, and my viewpoint cosmopolitical. I am therefore an apatride writer, without a culture, without a country, without a language. I am a soul that moves from one body politic into another [...]. My culture is weak, dead, and there is none I wish to embrace. I might sound rather arrogant or, worse, an idiot. However, this imperfect position will be in the future the only viable position in a world of centrified slaves. (Dagnino and D'Alfonso, 2017)

\section{In Place of a Conclusion}

As we have seen, bilingualism and self-translation may be used to question or redefine one's cultural identity ${ }^{16}$ and to dislocate and decentralize contextual dominant idioms. I stress the word contextual because idioms become dominant depending on the context in which they are actively practiced and pursued. D'Alfonso's Italian, for instance, is perceived as a minority language in the Canadian context, but it is definitely lived as a dominant idiom by migrant or foreign writers trying to find their way into the Italian literary system. In this regard, D'Alfonso, like Parks, is considered an outsider whose Italian is not sufficiently refined or literary enough in the eyes of the local/national intelligentsia. As the Italian writer Francesca Marciano comments, "Italians haven't yet got rid of a cer-

16. In this regard, see also Wolf (2008). 
tain elitist and pretentious view of literary style. They still have to undergo the stylistic revolution that the English went through with its Hemingways, Carvers and Faulkners" (Dagnino and Marciano, 2017).

By his own admission, D'Alfonso started off self-translating with the aim of expanding his readership and acquiring literary recognition outside the stifling cultural and linguistic borders of French Quebec:

Most of my essays written in French have never been published in French. All my essays I had to translate and publish in English. My anti-nationalism $[\ldots]$ is clearly not appreciated by my French-language publishers [...]. (Dagnino and D'Alfonso, 2017)

D'Alfonso thus started off as a Widener, willing to expose his work to a wider, English-reading audience. In the process, though, he understood that he could also use self-translation as a tool to call into question the centrality of two of the most influential languages (and their related literary cultures) on the global scene-namely, English and French. Consequently, he assumed the role of a Decentralizer:

Translations are required to demonstratively promote the nation's agenda. This is why in many cases, it is the translator who is applauded and not the author of the original text. When critics speak of one translation being better than another, it is often because the translator has elaborated something that is uniquely national. We experience this reservation whenever we have to negotiate the French translation of an English-language writer: does the publisher hire a translator from Canada or one from France? This proves that language is irrefutably centralized. Whenever translation is decentralized, it is ignored. (Dagnino and D'Alfonso, 2017)

That is why D'Alfonso's self-translations may also be readquoting him-as "subversive acts, perhaps the most subversive acts in the world today" (ibid.). We should not forget that, indeed, we are dealing with a global literary scene in which, if we just look at the United States, the biggest publishing market on earth, only an infinitesimal part of published books are translations: "The sad statistics indicate that in the United States and the United Kingdom, for example, only two to three percent of books published each year are literary translations" (Grossman, 2011, n.p.). ${ }^{17}$ A closer look reveals an even worse state of affairs, as the two to three percent figure is

17. That is as opposed to 35\%-ish in Europe and Latin America, and who-could-say what percentage in Romania or Lebanon. 
considerably bolstered by technical manuals and other non-fiction texts. For literary fiction and poetry, the figure is actually closer to $0.7 \% .^{18}$

D'Alfonso's task of acting as a language dislocator through selftranslation is tremendously ambitious and perhaps defiantly hopeless, as he admits:

(Self-)Translation means leaving your windows open for the passersby... [But] who are we to want to pretend to have something new to offer to cultures that have shut tight the gates of national imagination? [...] If one considers that translations are rarely read and never reviewed, a translation is a waste of time for any writer who is content on reading himself and his buddies. Why read an author who introduces a worldview and works in a style totally foreign to yours? To do so would demonstrate an openness of spirit that is, in fact, atypical. (Dagnino and D'Alfonso, 2017)

\section{References}

Anselmi, Simona (2012). On Self-Translation: An Exploration in Self-Translators' Teloi and Strategies. Milan, LED.

Baker, Charlotte Anne (2017). "Translated from Gikuyu by the Author': Ngugi wa Thiongo's Self-Translation of Wizard of the Crow." In J. MisrahiBarak and S. Ravi, eds. Translating the Postcolonial in Multilingual Contexts. Montpellier, Presses universitaires de la Méditerranée, pp. 127-140.

Bassnett, Susan (2013). The Self-Translator as Re-Writer." In A. Cordingley, ed. Self-Translation: Brokering Originality in Hybrid Culture. London, Bloosmbury, pp. 13-26.

Beaujour, Elizabeth Klosty (1989). Alien Tongues: Bilingual Russian Writers of the 'First' Emigration. Ithaca, Cornell University Press.

Besemeres, Mary and Anna Wierzbicka, eds. (2007). Translating Lives: Living with Two Languages and Cultures. St. Lucia, University of Queensland Press.

Bhabha, Homi K. (1994). The Location of Culture. London and New York, Routledge.

Bourhis, Richard Y. (2001) "Reversing Language Shift in Quebec." In J. A. Fishman, ed. Can Threatened Languages be Saved? Reversing Language Shift, Revisited: A $21^{\text {st }}$ Century Perspective. Clevedon, Multilingual Matters, pp. 101-141.

Bueno García, Antonio (2003). “Le concept d'autotraduction.” In M. Ballard and A. El Kaladi, eds. Traductologie, linguistique et traduction. Arras, Artois Presses Université, pp. 265-278.

Calvet, Louis-Jean (1999). Pour une écologie des langues du monde. Paris, Plon.

18. See Morris (2015). 
Calvet, Louis-Jean (2006). Towards and Ecology of World Languages. Trans. Andrew Brown. Cambridge, Polity.

Canton, Lucia (2015). "Fabrizio's Confusion." English-Canadian Writers. Faculty of Humanities and Social Sciences, Athabasca University. 12 February. [http://canadian-writers.athabascau.ca/english/writers/adalfonso /essay.php].

Casanova, Pascale (2004). The World Republic of Letters. Trans. M. B. DeBevoise. Cambridge, Harvard University Press.

Casanova, Pascale (2009). "Consecration and Accumulation of Literary Capital: Translation as Unequal Exchange.” In M. Baker, ed. Translation Studies. Critical Concepts in Linguistics. Vol. II. London and New York, Routledge, pp. 85-107.

Castro, Olga, Sergi Mainer and Svetlana Page (2017). "Introduction: SelfTranslating, from Minorisation to Empowerment.” In O. Castro, S. Mainer and S. Page, eds. Self-Translation and Power. Negotiating Identities in European Multilingual Contexts. London, Palgrave Macmillan, pp. 1-22.

Dagnino, Arianna (2015). Transcultural Writers and Novels in the Age of Global Mobility. West Lafayette, Purdue University Press.

Dagnino, Arianna (2016). "Re-discovering Alessandro Spina's Transculture/ ality in The Young Maronite." Humanities, 5, 2. [https://www.mdpi.com/ 2076-0787/5/2/42/htm].

Dagnino, Arianna and Antonio D'Alfonso (2017). Interview with Antonio D'Alfonso. Vancouver, 27 September.

Dagnino, Arianna and Francesca Duranti (2017). Interview with Francesca Duranti. Lucca, 2 July.

Dagnino, Arianna and Francesca Marciano (2017). Interview with Francesca Marciano. Vancouver, 14 September.

D'Alfonso, Antonio (1988). The Other Shore. Toronto, Guernica.

D’Alfonso, Antonio (1990). Avril ou l'anti-passion. Montréal, VLB éditeur.

D’Alfonso, Antonio (1995). Fabrizio's Passion. Toronto, Guernica.

D'Alfonso, Antonio (2004). Antigone. Toronto, Lyrical Myrical.

D’Alfonso, Antonio (2013). Un ami, un nuage. Montréal, Éditions du Noroît.

D'Alfonso, Antonio (2014). The Irrelevant Man. Toronto, Guernica Editions.

D’Alfonso, Antonio (2018). Antigone. Montréal, Éditions du Noroît.

Deleuze, Gilles and Félix Guattari (1975). Kafka. Pour une littérature mineure. Paris, Éditions de Minuit.

De Swaan, Abram (1993). "The Evolving European Language System: A Theory of Communication Potential and Language Competition." International Political Science Review, 14, 3, pp. 241-256.

De Swaan, Abram (2001). Words of the World: The Global Language System. Cambridge, Polity Press.

Epstein, Mikhail (2009). "Transculture: A Broad Way Between Globalism and Multiculturalism." The American Journal of Economics and Sociology, 68, 1, pp. 327-351. 
Ferraro, Alessandra and Rainier Grutman (2016). "Avant-propos. L'autotraduction littéraire: cadres contextuels et dynamiques textuelles.” In A. Ferraro and R. Grutman, eds. L'Autotraduction littéraire. Perspectives théoriques. Paris, Classiques Garnier, pp. 7-17.

Fitch, Brian T. (1988). Beckett and Babel. An Investigation into the Status of the Bilingual Work. Toronto, University of Toronto Press.

Galloway, Nicola and Heath Rose (2015). Introducing Global Englishes. New York, Routledge.

Gentes, Eva (2016). “... et ainsi j’ai décidé de me traduire. Les moments déclencheurs dans la vie littéraire des autotraducteurs.” In A. Ferraro and R. Grutman, eds. L'Autotraduction littéraire. Perspectives théoriques. Paris, Classiques Garnier, pp. 85-101.

Grenoble, Lenore and Adam Roth Singerman (2017). "Minority Languages." Oxford Bibliographies. Oxford University Press. [https://www.oxford bibliographies.com/view/document/obo-9780199772810/obo-9780199 772810-0176.xml].

Grossman, Edith (2011). Why Translation Matters. New Haven, Yale University Press.

Grutman, Rainier (2009). "Self-translation.”In M. Baker and G. Saldanha, eds. Routledge Encyclopedia of Translation Studies. $2^{\text {nd }}$ ed. London and New York, Routledge, pp. 257-260.

Grutman, Rainier (2011). “Diglosia y autotraducción.” In X. M. Dasilva and H. Tanqueiro, eds. Aproximaciones a la autotraducción. Vigo, Editorial Academia del Hispanismo, pp. 69-91.

Grutman, Rainier (2013). "A Sociological Glance at Self-Translation and SelfTranslators.” In A. Cordingley, ed. Self-Translation: Brokering Originality in Hybrid Culture. London, Bloomsbury, pp. 63-80.

Grutman, Rainier (2015). "Lautotraduction: de la galerie de portraits à la galaxie des langues.” Glottopol, 25, pp. 14-30.

Grutman, Rainier (2016). "Non si tratta di una semplice auto-traduzione': il ruolo della riscrittura nella postura d'autore di Amara Lakhous." In C. Denti, L. Quaquarelli and L. Reggiani, eds. Voci della traduzione/Voix de la traduction, mediAzioni, 21. [http://www.mediazioni.sitlec.unibo.it/ images/stories/PDF_folder/document-pdf/21-2016/2\%20grutman.pdf]

Grutman, Rainier and Trish Van Bolderen (2014). "Self-Translation." In S. Bermann and C. Porter, eds. A Companion to Translation Studies. Oxford, Wiley-Blackwell, pp. 323-330.

Hoffman, Eva (1989). Lost in Translation: A Life in a New Language. New York, Penguin Books.

Hokenson, Jan (2013). "History and Self-Translation." In A. Cordingley, ed. Self-Translation: Brokering Originality in Hybrid Culture. London, Bloomsbury, pp. 39-60.

Hokenson, Jan Walsh and Marcella Munson (2007). The Bilingual Text: History and Theory of Literary Self-Translation. Manchester, St. Jerome. 
Huston, Nancy (1999). Nord perdu. Paris, Actes Sud.

Kellman, Steven G. (2017). “Jhumpa Lahiri Goes Italian.” New England Review, 38, 3. [http://www.nereview.com/vol-38-no-2-2017/jhumpa-lahiri-goesitalian/].

Krause, Corinna (2007). Eadar Dà Chànan: Self-Translation, the Bilingual Edition and Modern Scottish Gaelic Poetry. Ph.D. thesis. School of Celtic and Scottish Studies, The University of Edinburgh. Unpublished. [https:// pdfs.semanticscholar.org/5d57/12188c48919e711c07dc6cbbb0737e200 dd1.pdf].

Lagarde, Christian (2015). “Des langues minorées aux 'langues mineures': autotraduction littéraire et sociolinguistique, une confrontation productive." Glottopol, 25. [http://glottopol.univ-rouen.fr/telecharger/ numero_25/gp125_00lagarde.pdf].

Lahiri, Jhumpa (2015). In altre parole, Parma, Guanda, pp. 52-53.

Leyshon, Cressida (2018). "Jhumpa Lahiri on Writing in Italian." The New Yorker, 22 January. [https://www.newyorker.com/books/this-week-infiction/fiction-this-week-jhumpa-lahiri-2018-01-29].

Morris, Bill (2015). "Why Americans Don't Read Foreign Fiction." The Daily Beast, 4 February. [https://www.thedailybeast.com/why-americans-dontread-foreign-fiction].

Nannavecchia, Tiziana (2016). Translating Italian-Canadian Migrant Writing to Italian: A Discourse Around the Return to the Motherland/Tongue. Ph.D. thesis. School of Translation and Interpretation, University of Ottawa. Unpublished.

Parks, Tim (2000). "Perils of Translation." The New York Review of Books, 20 January, pp. 53-54.

Recuenco Peñalver, Maria (2015). "Encounter with André Brink: Looking on... Self-Translation." Research in African Literatures, 46, 2, pp. 146-156.

Phillipson, Robert (2009). "Disciplines of English and Disciplining by English." The Asian EFL Journal, 11, 4, pp. 8-30.

Pivato, Joseph (2002). "Lost in 3-D: Di Cicco, di Michele, D’Alfonso." In L. Canton, ed. The Dynamics of Cultural Exchange. Montreal, Cusmano, pp. 243-256.

Popovič, Anton (1976). A Dictionary for the Analysis of Literary Translation. Edmonton, University of Alberta.

Shafiq, Muna (2006). "Linguistic Hybridity in Gloria Anzaldúa's Borderlands, Antonio D'Alfonso's Avril ou L'anti-passion, and Hiromi Goto's Chorus of Mushrooms." In M. Gonzalez and F. Tolron, eds. Translating Identity and the Identity of Translation. Newcastle, Cambridge Scholars Press, pp. 3-19.

Ugresic, Dubravka (2014). Europe in Sepia. Trans. David Williams. Rochester, Open Letter.

Welsch, Wolfgang (2010). "Was ist eigentlich Transkulturalität?" In L. Darowska, T. Lüttenberg and C. Machold, eds. Hochschule als transkultureller Raum? Kultur, Bildung und Differenz in der Universität. Bielefeld, Transcript, pp. 39-66. 
Wolf, Michaela (2008). "Interference from the Third Space? The Construction of Cultural Identity through Translation." In M. Muñoz-Calvo, C. BuesaGómez and M. A. Ruiz-Moneva, eds. Nerw Trends in Translation and Cultural Identity. Newcastle upon Tyne, Cambridge Scholars Publishing, pp. 11-20.

Whyte, Christopher (2002). "Against Self-Translation." Translation and Literature, 11, 1, pp. 64-71.

Arianna Dagnino

Department of French, Hispanic \& Italian Studies

University of British Columbia Vancouver, British Columbia, Canada arianna.dagnino@ubc.ca 